\title{
Perubahan Perilaku Petani Akibat Adanya Keberadaan dan Peran PPL dalam Usahatani Padi Sawah di Desa Makmur Jaya Kecamatan Betara Kabupaten Tanjung Jabung Barat
}

\author{
Bimo Bagus Saputro, Asmaida, Rizki Gemala Busyra \\ Fakultas Pertanian Universitas Batanghari Jambi \\ Email : bimobaqus450@gmail.com, asmaida.svandri@yahoo.co.id, gie bs@yahoo.com
}

\begin{abstract}
Desa Makmur Jaya is located in Betara District, Tanjung Jabung Barat Regency and this village is one of the village that has potential in agriculture, in 2017 this village is a land area of 250 hectares wich was used for lowland rice farming with production reaching 315 tons and productivity of 1,26 tons/hectare. Increasing activities in cultivating rice fields is a form of change that is inseparable from the role and fresence of field agricultural instructors, while also influencing changes in farmer behavior. Besides that prosperous villages also have farmer groups that have been formed from 2006 by PPL. The purpose of the behaviour of rice farmers due to PPL in the study area. Behavioral changes that one to be studied area the behavior of farmers before and after the existence of PPL in the aspects of seedling, the system of growing rice, types of fertilizer used in pest control and rice plants, the ability to overcome problems with rice cuktivation and the ability to form farmer groups. The type of data used is the type of cross section data with the type of ordinal measuring scale. The data is source from primary data and sekunder data, the primary data is obtained from the regionsl office directly through the questionnaire while the secondary data is taken from the relevant agencies. The methods used is survey method. In this case the sample is farmers who cultivate paddy field before 2006 to 2018. Data about respondents is a promising data source with data collection techniquws by observation, intervies and referring to the topic and tittle of the research proportional random sampling techniqus of sampling with 50 RTP samples.Data from research result are abstracted, tabulated and the average frequency is calculated and then presented for qualitative data, score is given to find out changes in farmer behavior before and after the presence of PPL, namely by adding up all the scores from the farmers sample then continuing to divide each aspect with two categories, namely the inadeguate category and the able category then analyzed using then wilcoxon martch pairs test using a 95\% convidents level. The results of he study were using the wilcoxon test, 95\% confidence level of a significant level $Z$ with the formula (Siregar, S 2015) yielding a $Z$ count volve of $-6,15$ which compared to the $Z$ table valv of 1,96 was greater than $Z$ counted and taken there was a change in the behavior of the sample farmers in farming paddy rice is covered and after PPL.
\end{abstract}

Keyword:

PPL, Behaviour Change, The Presence and role of PPL.

\section{PENDAHULUAN}

Maju dan berkembangnya pola pikir masyarakat petani untuk menerima berbagai ilmu dan teknologi pertanian merupakan modal awal yang sangat berperan untuk mewujudkan keberhasilan pembangunan pertanian. Keberadaan penyuluh sebagai pendamping dan mitra kerja petani di tuntut untuk melakukan perubahan-perubahan kearah yang lebih baik melalui kerjasama dalam merancang, melaksanakan, dan memonitor serta mengevaluasi seluruh kegiatan usahatani. Menurut Suhardiyono (1992), menyatakan bahwa suatu tanggung jawab untuk membawa perubahan yang progresif di bidang pertanian terletak di tangan penyuluh, karena di tangan mereka petani mengharapkan bimbingan yang diperlukan untuk meningkatkan kesejahteraan petani dan keluarganya.

Desa Makmur Jaya Kecamatan Betara Kabupaten Tanjung Jabung Barat merupakan salah satu desa yang memiliki potensi dibidang pertanian, pada tahun 2017 desa ini memiliki luas lahan $250 \mathrm{Ha}$ yang di gunakan untuk usahatani padi sawah dengan hasil produksi mencapai 315 Ton dan produktivitas 1,26 Ton/Ha.

Dengan keberadaan dan peranan penyuluh pertanian lapangan (PPL) di desa memberpadi sawah dampak terhadap perubahan-perubahan perilaku petanidalam berusahatani padi sawah. Perubahan yang terjadi akibat adanya peranan dan keberadaan PenyuluhPertanian Lapangan (PPL) tentu akan menimbulkan berbagai dampak perilaku pertanian dalam berusahatani padi sawah,maka berdasarkan uraian dan penjelasan tersebut perlu dilakukan penelitian tentang Perilaku Petani Dalam Usahatani Padi sawah di Desa Makmur Jaya Kecamatan Betara Kabupaten Tanjung Jabung Barat.

Adapun tujuan dari penelitian ini adalah untuk mendeskripspadi sawah tentang keberadaan dan peranan yang di berpadi sawah PPL dalam berusahatani padi sawah, mendeskripspadi sawah perilaku petani dalam berusahatani padi sawah sebelum dan setelah adanya keberadaan dan peranan PPL dan menganalisis perbedaaan prilaku petani dalam berusahatani padi sawah sebelum dan setelah adanya keberadaan dan peranan PPL di Desa 
Makmur jaya Kecamatan Betara Kabupaten Tanjung Jabung barat.

\section{METODOLOGI PENELITIAN}

Penelitian ini dilakukan di Desa Makmur Jaya Kecamatan Betara Kabupaten Tanjung Jabung Barat, dengan pertimbangan bahwa kegiatan pertanian dan PPL di Desa Makmur Jaya Kecamatan Betara Kabupaten Tanjung Jabung Barat berjalan cukup aktif, serta mayoritas petani didaerah adalah melakukan usaha padi sawah. Jenis data yang dikumpulkan adalah jenis data (cross section) dengan jenis skala ukur ordinal. Metode yang digunakan dalam pengumpulan data pada penelitian ini adalah menggunakan metode survey, yaitu penelitian dengan cara pengambilan sampel dari suatu populasi dan menggunakan kuisioner sebagai alat pengumpulan data dan menjelaskan hubungan kausal antara variabelvariabel melalui pengujian hipotesis (Singarimbun dan Effendi , 1995).Untuk pengambilan besarnya sampel pada masingmasing kelompok tani di Desa Makmur Jaya digunakan metode sampel berdasarkan acak kelompok (proposional random sampling), dengan rumus (Nazir, 1998) sebagai berikut : ni $=\frac{N i}{N} n$

Dimana :

ni = Jumlah total sub sampel

rumah tangga petani

$\mathrm{Ni}=$ Jumlah total sub populasi

rumah tangga petani $\mathrm{n}=$ Jumlah total sampel

rumah tangga petani

$\mathrm{N}=$ Jumlah total populasi

rumah tangga petani

Sebagai populasi dalam penelitian ini adalah petani yang masih tetap berusahatani padi sawah sampai saat penelitian dilakukan atau masyarakat yang berusahatani padi sawah sebelum sampai setelah adanya PPL, yaitu berjumlah 98 RTP dari 439 RTP. Dari 98 RTP diambil sebesar 50 RTP yang dipilih secara sengaja untuk dijadikan sampel penelitian.

Analisis untuk mendeskrips kegiatan usahatani padi sawah, keberadaan dan peranan PPL serta perilaku petani dalam berusahatani padi sawah dianalisis secara deskriptif. Sedangkan untuk menganalisis perbedaaan prilaku petani dalam berusahatani padi sawah sebelum dan setelah adanya keberadaan dan peranan PPL dianalisis dengan menggunakan Uji Wilcoxon (Siregar, S, 2015) dengan rumus :

$$
Z=\frac{T-\mu_{T}}{\sigma_{T}}=\frac{T-\frac{n(n+1)}{4}}{\sqrt{\frac{n(n+1)(2 n+1)}{24}}}
$$

Dimana :

$\mathrm{T}=$ Nilai yang lebih kecil antara $\mathrm{T}^{+}$

dan $\mathrm{T}^{-}$

$\mathrm{n}=$ Jumlah sampel

\section{HASIL DAN PEMBAHASAN \\ Karakteristik Petani}

Karakteristik petani padi sawah di Desa Makmur Jaya yang dibahas dalam penelitian ini meliputi umur, jumlah tanggungan keluarga, tingkat pendidpadi sawah dan lamanya pengalaman berusahatani, sebagaimana terlihat pada Tabel 1 .

Tabel 1. Karakteristik Petani Padi sawah di Desa Jembatan Mas Tahun 2018

\begin{tabular}{clc}
\hline No & & Karakteristik \\
\hline 1 & Umur & 49 Tahun \\
2 & Jumlah Anggota Tanggungan Keluarga & 4 Orang \\
3 & Tingkat Pendidpadi sawah & SMP \\
4 & Pengalaman Berusaha Budidaya Padi sawah & 23 Tahun \\
\hline Sumber : Data Primer yang diolah, Tahun 2018
\end{tabular}

Berdasarkan Tabel 1 di atas, umur petani padi sawah rata-rata 49 tahun. Menurut Sueharjo dan Patong (1993), usia yang dikatakan produktif adalah mereka yang bekerja pada usia 15 sampai 55 tahun dimana pada usia tersebut seseorang memiliki kemampuan fisik yang baik dan produktif untuk mengelola usahatani yang dikerjakannya.

Jumlah anggota keluarga petani padi sawah rata-rata anggotanya berjumlah 4 orang. Jumlah anggota yang menjadi tanggungan keluarga merupakan salah satu faktor yang mempengaruhi keberhasilan usaha. Dan secara fungsional dapat dimanfaatkan sebagai modal sumberdaya/tenaga kerja dalam usaha budidaya ikan, sekaligus sebagai beban tanggungan keluarga yang nantinya akan berpengaruh terhadap ekonomi keluarga petani tersebut.

Menurut Hernanto (1989), tingkat pendidikan petani padi sawah akan mempengaruhi cara mereka dalam berfikir, menerima dan mencoba hal baru.Tingkat pendidikan petani padi sawah di daerah penelitian sebagian besar adalah tamatan SMP.

Pengalaman petani dalam berusahatani padi sawah rata-rata 23 tahun, hal ini menunjukkan bahwa petani telah berpengalaman dalam berusahatani padi sawah. Dengan demikian diharapkan petani dapat melakukan usahanya dengan baik dan maksimal serta lebih terampil dalam proses pengambilan keputusan dalam pengelolaan usahanya, sehingga petani mampu meningkatkan produksi usaha yang pada akhirnya 
dapat meningkatkan pendapatan. Pernyataan ini sependapat dengan pernyataan Asmaida (2017), yaitu pengalaman petani dapat dijadikan tolak ukur untuk pengembangan usaha dimasa yang akan datang. Semakin lama pengalaman berusahanya, maka petani semakin banyak pengetahuannya dalam berusaha. Petani dengan pengalaman berusaha yang cukup lama akan sangat hati-hati dalam menerima dukungan dari pemerintah dan menerima inovasi yang dianggap baru, karena petani akan mempertimbangkan resiko kegagalan bila menerima dukungan dari pemrintah atau menerapkan inovasi tersebut.

\section{Gambaran Keberadaan dan Peranan PPL Dalam Usahatani Padi Sawah}

PPL masuk ke daerah penelitian untuk pertama kalinya yaitu pada Tahun 2006. Kemudian membentuk kelompok tani yang terdiri dari 3 kelompok tani yaitu kelompok tani Surya Gemilang I, Surya Gemilang II dan Lestari gemilang. PPL membuat Pos Pelayanan Penyuluh (POSLUH) yang kegunaan adalah untuk menerima keluhan petani serta tempat petani menemui PPL untuk berkonsultasi tentang kegiatan budidaya tanaman padi sawah. PPL turun ke lapangan setiap 2 kali dalam seminggu. PPL mengarahkan segala sesuatu yang dilakukan petani dilapangan mulai dari pengaplikasian cara mengolah lahan yang baik dan benar. Materi pertama kali yang disampaikan PPL yaitu tentang memilih padi yang tepat untuk kondisi cuaca dan tanah di Desa Makmur Jaya, sehingga petani mempunyai pengetahuan tentang jenis-jenis padi yang akan ditanam dan yang dapat memberikan keuntunga yang lebih bagi petani. Selain hal tersebut PPL memberikan informasi mengenai kelebihan dan kekurangan setiap sistem tanam padi yaitu tentang sistem jajar legowo, sistem tegel dan campuran. Peran PPL adalah menentukan jadwal tanam padi sawah yang baik sesuai dengan perkiraan cuaca yang terjadi didaerah penelitian. Hal ini sangat membantu petani yaitu dengan mendapatkan informasi keadaan iklim atau wakyu terjadi musim panca roba. PPL terus membimbing petani untuk bisa membuat usulanusulan berupa bnantuan kepada Dinas Pertanian Kabupaten Tanjung Jabung Barat maupun Dinas Pertanian Provinsi Jambi serta instansi terkait lainnya untuk bisa memperoleh bantuan bibit dan saprodi sehingga dapat menekan biaya usahatani seminim mungkin.

1. Perilaku Petani Dalam Usahatani Padi Sawah Sebelum Dan Setelah Adanya Keberadaan Dan Peran PPL Di Desa Makmur Jaya Dalam Usahatani Padi Sawah.

a. Pengolahan lahan
Sebelum adanya keberadaan dan peran PPL dilihat dari 50 RTP terdapat 31 RTP (62\%) tidak mampu mengolah lahan usahatani padi sawah dengan baik dan 19 RTP (38\%) yang mampu mengolah lahan dengan baik. Petani di katakan berkategori tidak mampu ini terlihat dari petani dalam berusaha padi sawah hanya mampu melakukan pembersihan pematang sawah dan pembajakan lahan sawah. Sesudah adanya keberadaan dan peran PPL jumlah petani yang berkategori tidak mampu mengolah lahan berkurang menjadi 21 RTP (42\%) dan terdapat peningkatan jumlah petani yang mampu mengelolah usahatani padi sawah menjadi 29 RTP (58\%). Artinya terdapat 10 orang petani dalam mengelola lahan kemampuanya meningkat, yaitu petani sudah mulai melakukan pembersihan saluran air, pematang sawah, membajak dan pencangkulan lahan sawah.

b. Pemilihan Benih

Sebelum adanya keberadaan dan peran PPL dilihat dari 50 RTP terdapat 35 RTP (70\%) yang tidak mampu menanam padi dengan baik dan benar dan hanya terdapat 15 RTP (30\%) yang mampu menanam padi dengan baik dan benar. Petani dikatakan berkategori tidak mampu menanam padi yang baik dan benar, karna petani hanya melakukan cara sistem campuran dan tidak beraturan. Sesudah adanya keberadaan dan peran PPL terdapat 25 RTP (50\%) yang tidak mampu menanam padi dengan baik dan benar dan terdapat 25 RTP (50\%) mampu menanam padi dengan baik dan benar. Dimana terdapat 10 orang petani dalam menanam padi kemampuanya meningkat, yaitu menanam padi dengan cara sistem jajar legowo dan tegel.

\section{c. Pemupukan}

Petani dikatakan berkategori tidak mampu memupuk dengan baik dan benar karena petani hanya melakukan pemupukan dengan menggunakan pupuk Urea dan NPK dan juga tidak sesuai dosis. Terdapat 38 RTP (76\%) belum mampu melakukan pemupukan dengan benar, dan 12 RTP (24\%) yang mampu melakukan pemupukan dengan jenis, dosis dan cara pemupukan yang tepat dan benar. Sesudah adanya keberadaan dan peran PPL terdapat 15 RTP (30\%) yang tidak mampu melakukan pemupukan dengan jenis, cara dan dosis pemupukan yang tepat dan terdapat 35 RTP (70\%) mampu melakukan pemupukan dengan jenis pupuk Urea, NPK, KCL, cara dan 
dosis pemupukan yang tepat dan berimbang.

d. Hama dan Penyakit Padi

Petani dikatakan berkategori tidak mampu mengendalikan hama dan penyakit karna petani dalam mengatasi hama dan penyakit masih menggunakan pestisida dan kadang tanpa melakukan pengendalian hama. Terdapat 44 RTP (88\%) yang tidak mampu mengendalikan hama dan penyakit tanaman padi dan hanya terdapat 6 RTP (12\%) yang mampu mengendalikan hama dan penyakit tanaman padi. Sesudah adanya keberadaan dan peran PPL terdapat 28 RTP (56\%) yang tidak mampu dalam mengendalikan hama dan penyakit tanaman padi serta terdapat 22 RTP (44\%) mampu mengendalikan hama dan penyakit tanaman padi.

\section{e. Masalah Berusahatani}

Petani dikatakan berkategori tidak mampu dalam mengatasi masalah karena petani dalam mengatasi masalah yang ada selalu meminta pendapat orang lain dan keluarga atau membiarkan saja masalah yang terjadi tersebut. Sesudah adanya keberadaan dan peran PPL terdapat 19 RTP (38\%) yang tidak mampu mengatasi masalah berusahatani dan terdapat 31 RTP (62\%) mampu mengatasi masalah berusahatani.

\section{f. Pembentukan Kelompok Tani}

Sebelum adanya keberadaan dan peran PPL dilihat dari 50 RTP terdapat 43 RTP (86\%) yang tidak mampu membentuk kelompok tani dan hanya terdapat 7 RTP (14\%) yang mampu membentuk kelompok tani. Petani di kategorikan tidak mampu dalam membentuk kelompok tani karna petani dalam berusahatani tidak ada kelompok tani. Sesudah adanya keberadaan dan peran PPL terdapat 3 RTP (6\%) yang tidak mampu membentuk kelompok tani dan terdapat 47 RTP (94\%) mampu membentuk kelompok tani. Dimana terdapat 40 orang petani dalam membentuk kelompok kemampun meningkat. Petani sudah bisa membentuk kelompok tani dengan struktur keanggotaan yang jelas dan ada program kerja.

\section{Perbedaan Perilaku Petani Berdasarkan Tes Wilcoxon}

Secara keseluruhan dapat dilihat bahwa perilaku petani padi sawah di Desa Makmur Jaya Kecamatan Betara Kabupaten Tajung Jabung Barat mengalami perubahan sebelum dan sesudah adanya PPL.
Berdasarkan hasil analisis uji Wilcoxon terhadap perubahan perilaku petani dalam berusahatani padi sawah di Di Desa Makmur Jaya, menghasilkan Z hitung sebesar $-6,15$ yang lebih kecil dari harga $Z$ tabel sebesar 1,96 pada taraf signifpadi sawah $\alpha / 2=0.025$, yaitu menolak $\mathrm{H}_{\mathrm{o}}$ dan menerima $\mathrm{H}_{\mathrm{a}}$. Artinya terdapat perbedaaan prilaku petani dalam berusahatani padi sawah sebelum dan setelah adanya keberadaan dan peranan PPL Desa Makmur Jaya Kecamatan Betara Kabupaten Tanjung Jabung Barat.

\section{SIMPULAN}

1. Peranan PPL dan keberadaannya memberikan pengaruh yang positif bagi petani sehingga mampu mengubah pola fikir petani ke arah yang lebih maju dalam hal pengolahan lahan, pemilihan bibit, pemupukan, pengendalian hama dan penyakit, mengatasi masalah dalam berusahatani dan kemampuan membentuk kelompok tani.

2. Hasil uji statistic menunjukan perilaku petani padi sawah di Desa Makmur Jaya Kecamatan Betara Kabupaten Tanjung Jabung Barat mengalami perbedaan sebelum dan setelah adanya PPL.

\section{DAFTAR PUSTAKA}

Asmaida, 2017. Efisiensi Alokatif Faktor-Faktor Produksi Dan Pendapatan Usahatani Padi (Oryza Sativa L.) (Studi Kasus Di Desa Simpang Datuk Kecamatan Nipah Panjang Kabupaten Tanjung Jabungtimur). Fakultas Pertanian Universitas Batanghari Jambi. Jurnal IImiah Media Agribisnis Vol. 2 No $2: 1-12$.

BP4K. 2017. Penyuluh Tanjab barat. Badan Penyuluh Pertanian. Kabupaten Tanjung Jabung Barat.

Departemen Pertanian. 2009. Kebijakan Teknis Program Pengembangan Usaha Agribisnis Perdesaan.Departemen Pertanian. Jakarta.

Kartosapoetro, A.G. 1996. Teknologi Penyuluh Pertanian. Bina Aksara. Jakarta.

Moh Nazir. 1998. Metode Penelitian. Ghalia Indonesia. Jakarta.

P4. 2001. Pusat Perkembangan Penyuluhan Pertanian. Tanjung Jabung Barat.

Pusat Pengembangan Penyuluhan Pertanian. 2001. Standarisasi sarana dan Prasarana Kelembagaan Penyuluhan Pertanian di Kabupaten. Deptan Jakarta.

Santoso, S. 2010. Statistik Nonparametrik Konsep dan Aplikasi dengan SPSS. PT. Elex Media Komputindo. Jakarta.

Singarimbun, Masri dan Efendi. 1995. Metode Penelitian Survei. Pustaka LP3ES. Jakarta. 
Suhardiyono, L. 1992. 'Penyuluhan Petunjuk Bagi Penyuluh Pertanian. Erlangga. JakartaSantoso, S. 2010. Statistik Nonparametrik Konsep dan Aplikasi dengan SPSS. PT. Elex Media Komputindo. Jakarta.

Van Den Ban. A. W. dan H. S Hawkins. 1999.

Penyuluhan Pertanian. Kanisius.

Yogyakarta. 